\title{
TU/e EmonOWEN

\section{Microparticles in a RF plasma under hyper gravity conditions}

\section{Citation for published version (APA):}

Beckers, J., Stoffels, W. W., Ockenga, T., Wolter, M., \& Kersten, H. (2009). Microparticles in a RF plasma under hyper gravity conditions. In IEEE International Conference on Plasma Science (ICOPS 2009) , 1-5 June 2009, San Diego, CA (pp. 5227229-). Institute of Electrical and Electronics Engineers. https://doi.org/10.1109/PLASMA.2009.5227229

DOI:

10.1109/PLASMA.2009.5227229

Document status and date:

Published: 01/01/2009

\section{Document Version:}

Publisher's PDF, also known as Version of Record (includes final page, issue and volume numbers)

\section{Please check the document version of this publication:}

- A submitted manuscript is the version of the article upon submission and before peer-review. There can be important differences between the submitted version and the official published version of record. People interested in the research are advised to contact the author for the final version of the publication, or visit the $\mathrm{DOI}$ to the publisher's website.

- The final author version and the galley proof are versions of the publication after peer review.

- The final published version features the final layout of the paper including the volume, issue and page numbers.

Link to publication

\section{General rights}

Copyright and moral rights for the publications made accessible in the public portal are retained by the authors and/or other copyright owners and it is a condition of accessing publications that users recognise and abide by the legal requirements associated with these rights.

- Users may download and print one copy of any publication from the public portal for the purpose of private study or research.

- You may not further distribute the material or use it for any profit-making activity or commercial gain

- You may freely distribute the URL identifying the publication in the public portal.

If the publication is distributed under the terms of Article 25fa of the Dutch Copyright Act, indicated by the "Taverne" license above, please follow below link for the End User Agreement:

www.tue.nl/taverne

Take down policy

If you believe that this document breaches copyright please contact us at:

openaccess@tue.nl

providing details and we will investigate your claim. 


\title{
MICROPARTICLES IN A RF PLASMA UNDER HYPER GRAVITY CONDITIONS
}

\author{
J. Beckers, W. W. Stoffels \\ Eindhoven University of Technology, \\ Department of Applied Physics \\ $5600 \mathrm{MB}$, Eindhoven, the Netherlands \\ T. Ockenga, M. Wolter, H. Kersten \\ Christian-Albrechts-Universität zu Kiel, \\ AG Plasmatechnologie \\ D-24098 Kiel, Germany
}

For diagnostic purposes micrometer-sized particles can be used as floating electrostatic probes. Once injected into a complex rf plasma, these particles will become negatively charged and can be trapped in the plasma sheath due to an equilibrium of several forces working on them, e.g. the electrostatic force, gravity, drag forces and thermophoresis. Measuring for example the position of the particles in the plasma sheath and the interparticle distance while varying plasma parameters (power, pressure, temperature, gas etc.) gives important information about plasma properties like the ion flux and the sheath potential.

We experimentally investigated the behavior of micrometer sized particles inserted and trapped in a rf plasma under varying gravity conditions in a centrifuge. Here we present first results of those measurements. The experiments were carried out in a Perspex box containing a parallel plate capacitively coupled rf argon plasma at pressures between 20 and $115 \mathrm{~Pa}$. The typical forward power applied to the bottom electrode was $\sim 10$ Watt. The squared electrodes are separated $5 \mathrm{~cm}$ from each other and both contain centered holes in order to trap the particles in the created potential well. This also gains possibilities to observe particle behavior from below. The monodisperse particles which are made of melamineformaldehyde and have sizes ranging from 5 up to $12 \mu \mathrm{m}$ are illuminated by an expanded $532 \mathrm{~nm}$ laser beam. The height of the particles on which the forces are in equilibrium is measured from pictures collected with an onboard CCD camera. This whole setup is mounted on a centrifuge originally developed to study high pressure metal halide lamps under hyper gravity conditions [1].

Results show that under these condition particles can be trapped in the plasma sheath when the gravitational force is $2.6 \mathrm{~g}$ or less. When larger acceleration forces are applied the particles are lost from the discharge. Due to the increased apparent gravity of the particles in the centrifuge the height of the cloud above the powered bottom electrode decrease with

$\sim 2 \mathrm{~mm}$ when the acceleration force is increased from $1 \mathrm{~g}$ up to $2.6 \mathrm{~g}$.

1. A J Flikweert, T Nimalasuriya, G M W Kroesen, W W Stof fels, Plasma Sources Sci. Technol. 16 (2007) 606-613. 